\title{
An Increase in the Association of GluN2B Containing NMDA Receptors with Membrane Scaffolding Proteins Was Related to Memory Declines during Aging
}

\author{
Daniel R. Zamzow, ${ }^{1,2,3}$ Valerie Elias, ${ }^{2,3}$ Michelle Shumaker, ${ }^{2}$ Cameron Larson, ${ }^{2}$ and Kathy R. Magnusson ${ }^{1,2,3}$ \\ ${ }^{1}$ Molecular and Cellular Biology Program, ${ }^{2}$ Department of Biomedical Sciences, College of Veterinary Medicine, and ${ }^{3}$ Linus Pauling Institute, Oregon State \\ University, Corvallis, Oregon 97331
}

\begin{abstract}
The NMDA receptor is an important component of spatial working and reference memory. The receptor is a heterotetramer composed of a family of related subunits. The GluN2B subunit of the NMDA receptor appears to be essential for some forms of memory and is particularly vulnerable to change with age in both the hippocampus and cerebral cortex. GluN2B expression is particularly reduced in frontal cortex synaptic membranes. The current study examined the relationship between spatial cognition and protein-protein interactions of GluN2B-containing NMDA receptors in frontal cortex crude synaptosome from 3, 12, and 26-month-old C57BL/6 mice. Aged mice showed a significant decline in spatial reference memory and reversal learning from both young and middle-aged mice. Coimmunoprecipitation of GluN2B subunits revealed an age-related increase in the ratio of both postsynaptic density-95 (PSD-95) and the GluN2A subunit to the GluN2B subunit. Higher ratios of PSD-95/GluN2B and GAIP-interacting protein C-terminus (GIPC)/GluN2B were associated with poorer learning index scores across all ages. There was a significant correlation between GIPC/GluN2B and PSD-95/ GluN2B ratios, but PSD-95/GluN2B and GluN2A/GluN2B ratios did not show a relationship. These results suggest that there were more triheteromeric (GluN2B/GluN2A/GluN1) NMDA receptors in older mice than in young adults, but this did not appear to impact spatial reference memory. Instead, an increased association of GluN2B-containing NMDA receptors with synaptic scaffolding proteins in aged animals may have contributed to the age-related memory declines.
\end{abstract}

\section{Introduction}

One of the hallmarks of aging is cognitive decline. Spatial memory, the detailed recollection of one's surroundings, is critical for navigating through everyday life and exhibits a significant decline with age (Gallagher et al., 1993). Age-related spatial memory impairments in rodents are similar to those seen in humans and, as such, rodents have provided a suitable model for testing (Barnes, 1979).

The NMDA receptor is an ionotropic glutamate receptor that is essential for spatial memory tasks (Morris et al., 1986). The NMDA receptor is believed to be a tetramer consisting of several different subunits: GluN1, GluN2A-D, and GluN3A-B. Developmentally, GluN1, GluN2B, and GluN3A subunits all decrease with age to adulthood, whereas GluN2A and GluN3B subunits increase during development (Low and Wee, 2010). The NMDA subunit that may be the most essential for learning and memory is the GluN2B subunit. Transgenic mice that overexpressed the

\footnotetext{
Received Jan. 22, 2013; revised June 7, 2013; accepted June 14, 2013.

Author contributions: D.R.Z. and K.R.M. designed research;D.R.Z., V.E., M.S., C.L., and K.R.M. performed research; D.R.Z., V.E., M.S., C.L., and K.R.M. analyzed data; D.R.Z. and K.R.M. wrote the paper.

This work was supported by NIH Grant AG16322 to K.R.M. We thank Rachele Bochart, Amanda Watts, and Noreen Siddiqui for excellent technical assistance.

The authors declare no competing financial interests.

Correspondence should be addressed to Dr Kathy R. Magnusson, 307 Linus Pauling Science Center, Oregon State University, Corvallis, OR 97331. E-mail: Kathy.Magnusson@oregonstate.edu.

DOI:10.1523/JNEUROSCI.0312-13.2013

Copyright $\odot 2013$ the authors $\quad 0270-6474 / 13 / 3312300-06 \$ 15.00 / 0$
}

GluN2B subunit in the cortex or hippocampus showed a significant improvement in several forms of memory (Tang et al., 1999; Cui et al., 2011). Conversely, injections of the GluN2B subunitspecific antagonist, ifenprodil, or siRNA directed against the GluN2B subunit resulted in significant impairment of fear memory (Zhao et al., 2005).

The NMDA receptor is particularly vulnerable to change during aging, showing a decrease in binding density in the cerebral cortex and hippocampus (Muller et al., 1994). Decreases in NMDA receptor binding in the frontal cortex and hippocampus of aged animals are associated with poorer spatial memory (Scheuer et al., 1995). The greatest effects due to age on the NMDA receptor are evident in both mRNA and protein expression of GluN2B subunits in the cerebral cortex and hippocampus (Magnusson, 2000, 2002). However, aged mice also show a greater decline in protein expression of GluN2B in the synaptic membrane than in the tissue as a whole in the frontal cortex (Zhao et al., 2009), suggesting an additional effect of aging beyond subunit production.

PSD-95 is a member of the membrane associated guanylate kinase (MAGUK) family of proteins, which act as scaffolding molecules in glutamatergic synapses (Xu, 2011). NMDA receptors are concentrated and held at synapses by PSD-95 (Roche et al., 2001; Xu, 2011). Like the GluN2B subunit, protein expression of PSD-95 is diminished with age in the hippocampus of rats (VanGuilder et al., 2010). Though less characterized in neurons as compared with other MAGUK proteins, GAIP-interacting 
A

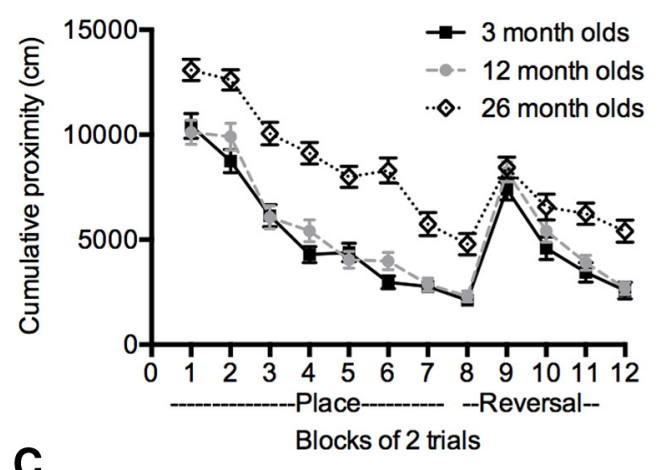

$\mathrm{c}$

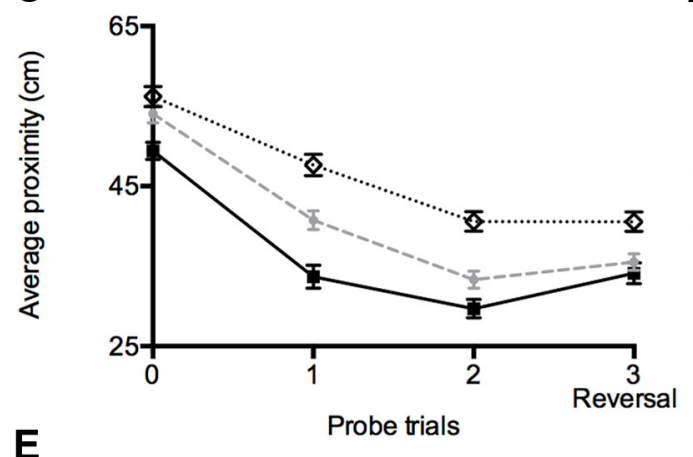

$\mathbf{E}$

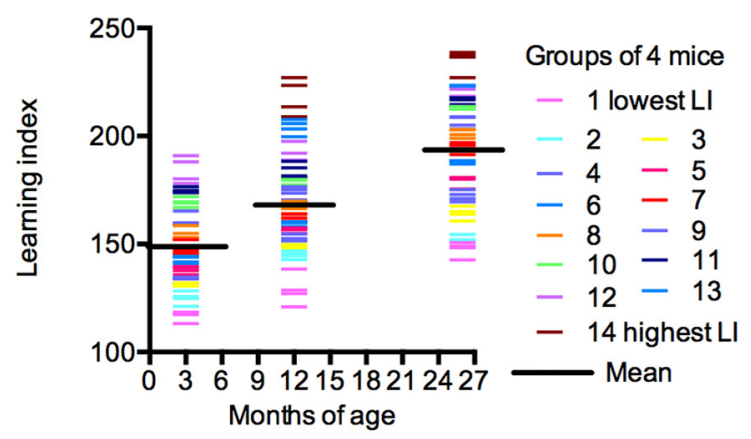

B

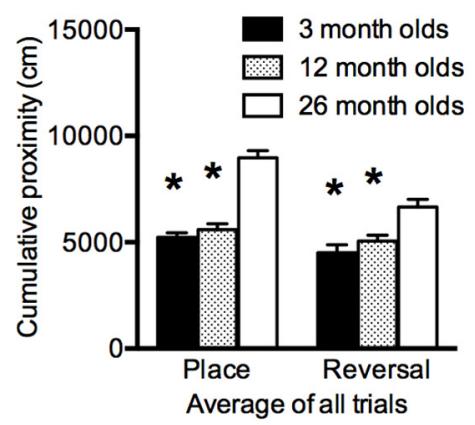

D

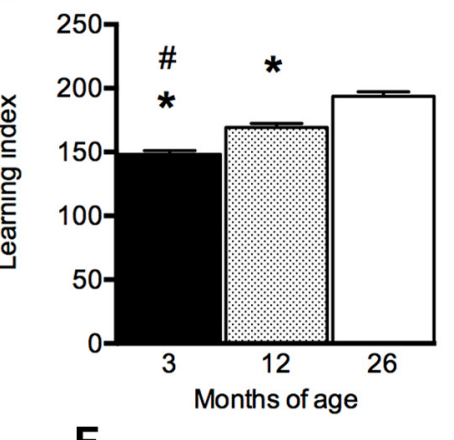

$\mathbf{F}$

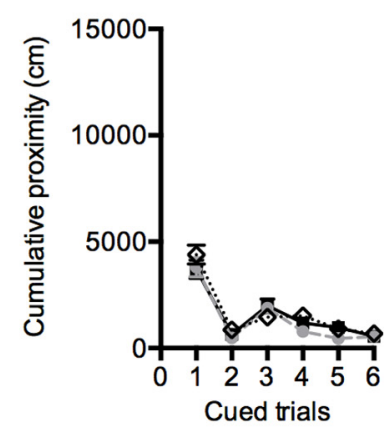

Figure 1. Effects of age on performance in memory tasks. $\boldsymbol{A}-\boldsymbol{D}, \boldsymbol{F}$, Performance for three ages, averaged across individual mice, for blocks of two place and reversal trials $(\boldsymbol{A})$ and averaged trials $(\boldsymbol{B})$ for spatial reference memory and cognitive flexibility, respectively; probe trials $(\boldsymbol{C})$ and learning index scores derived from probe trials $(\boldsymbol{D})$ for spatial reference memory, and cued control trials $(\boldsymbol{F})$ in the water maze. $\boldsymbol{E}$, Distribution of learning index scores for individual mice within the groups of four mice that were combined for protein analysis. Each group is represented by a different color; $p<0.05$ for difference from 12 -(\#) and $\left.26-{ }^{*}\right)$ month-olds $(N=48-56$; data $=$ mean \pm SEM).

protein C-terminus (GIPC) has been shown to interact with GluN2-containing NMDA receptors preferentially on extrasynaptic membranes (Yi et al., 2007). In the current study, we assessed the spatial reference memory of C57BL/6 mice of three different ages and quantified the interaction of GluN2B subunit with associated proteins in the frontal cortex.

\section{Materials and Methods}

Animals. A total of 304 male C57BL/6 mice from three age groups (3, 12, and 26 months of age) were used for the study. The older two ages were obtained from National Institute on Aging, NIH. Young mice were purchased from JAX mice, which stocks the NIH colony. They were fed ad libitum and housed under $12 \mathrm{~h}$ light/dark cycle. Animals were randomly divided into two behavioral groups; naive and behaviorally tested, with 48-56 animals in each age/behavioral group. Animals in the behaviorally tested group were subjected to a learning experience using the Morris water maze during the $12 \mathrm{~h}$ light cycle, as described below. Animals in the naive group were housed for the same amount of time as the behaviorally tested animals. After the behavioral testing, all animals were killed by exposure to $\mathrm{CO}_{2}$ and decapitated. The brains were harvested, frozen in dry ice, and stored at $-80^{\circ} \mathrm{C}$.
Behavioral testing. Spatial reference memory, cognitive flexibility and associative memory (cued control task) were tested using the Morris water maze as previously described (Das et al., 2012). Briefly, for the first $2 \mathrm{~d}$, mice were acclimated to the water maze, followed by $2 \mathrm{~d}$ of testing for spatial reference memory, $1 \mathrm{~d}$ of reversal training to test cognitive flexibility and $1 \mathrm{~d}$ of associative memory testing (cued control task). Place and probe trials were conducted in the presence and absence of the platform, respectively. There was a $1 \mathrm{~h}$ rest period after every four place trials and $2 \mathrm{~min}$ intertrial intervals between the other place trials.

Tissue subfractionation and lysis. Biochemical fractionation of the frontal cortex (rostral $4 \mathrm{~mm}$ cortex) was performed as previously described (Dunah and Standaert, 2001), with a few modifications. Briefly, tissue was homogenized on ice with a Dounce homogenizer in TE buffer $(10 \mathrm{~mm}$ Tris-HCl, pH 7.4, 1 mm EDTA, 1 mm EGTA) plus $320 \mathrm{~mm}$ sucrose and protease inhibitor cocktail (Sigma-Aldrich). Homogenate was centrifuged at $4^{\circ} \mathrm{C} 1000 \times g$ for $10 \mathrm{~min}$ and the resulting pellet (P1) was discarded. The supernatant (S1) was centrifuged at $4^{\circ} \mathrm{C} 10,600 \times g$ for $20 \mathrm{~min}$ to produce the crude synaptosome pellet, $\mathrm{P} 2$. The P2 was resuspended in $150 \mu$ l of DOC buffer (50 mu Tris- $\mathrm{HCl}, \mathrm{pH}$ 9.0, 1\% sodium deoxycholate and protease inhibitor cocktail) and lysed at $37^{\circ} \mathrm{C}$ for $45 \mathrm{~min}$ followed by addition of IP buffer ( 50 mм Tris-HCl, pH 7.4, 1 mм EDTA, 1 mм EGTA, $150 \mathrm{~mm} \mathrm{NaCl}, 1 \%$ Triton X-100 and protein inhibitor cocktail) and incubated while rotating at $4^{\circ} \mathrm{C}$. The total lysate was precleared with $100 \mu \mathrm{l}$ of 50:50 protein $\mathrm{A} / \mathrm{G}$ agarose bead slurry in IP buffer for $1 \mathrm{~h}$ while rotating at $4^{\circ} \mathrm{C}$. Protein determinations were made with Bio-Rad DC Protein Assay (Bio-Rad). To have enough protein for three precipitation replicates, four lysed samples of like age and behavioral group were pooled based on similarity of learning index (see below, Data analysis) for $N=11-14$.

Immunoprecipitation. A total of $500 \mu \mathrm{g}$ of lysed P2 was diluted in IP buffer to $500 \mu$ l. Diluted samples were incubated with $5 \mu \mathrm{l}$ of GluN2B antibody (NeuroMab) while rotating for $36 \mathrm{~h}$ at $4^{\circ} \mathrm{C}$ and precipitated by incubation with protein A/G agarose beads (Santa Cruz Biotechnology) for $2 \mathrm{~h}$ at $4^{\circ} \mathrm{C}$. Precipitated proteins were released from the beads by heating to $95^{\circ} \mathrm{C}$ for $5 \mathrm{~min}$ in Laemmli sample buffer.

Western blot. SDS-PAGE (7.5\%) was used for Western blotting as described previously (Zhao et al., 2009). Each gel contained four different micrograms loads $(1.5,3,6$, and $12 \mu \mathrm{g} /$ well $)$ of standards obtained from crude synaptosomes prepared from combined caudal cortices from all naive young animals. Protein samples from different age/treatment groups were loaded on each gel and analyzed in triplicate. Proteins were transferred to PVDF membranes and incubated overnight at $4^{\circ} \mathrm{C}$ in one of the following primary antibodies: GluN2B (Millipore), GluN2A or GIPC (Santa Cruz Biotechnology), PSD-95 (ThermoScientific), or GAPDH (Calbiochem). Membranes were rinsed and incubated in fluorescence-based secondary antibody (Rockland Immunochemicals). Bands were visualized by scanning in the LI-COR Odyssey imager.

Data analysis. Data for behavioral testing were analyzed as previously described (Das et al., 2012). Cumulative proximity measures, which reflect search distance from the platform, were used for the place, reversal and cued trials and average proximity and learning index (calculated for probe trials $0-2$ ), which reflects development of a spatial bias, were used for probe trials (Gallagher et al., 1993). Repeated-measures ANOVAs and Fisher's protected 
least significant difference were performed using data from individual animals. Brain tissue from four animals, with similar learning index scores (Fig. 1E), were combined for protein assessment. Behavioral data were averaged for each combination of four animals to provide a single value for use in correlational analysis with the protein results. Protein blots were analyzed using Li-Cor Odyssey software. Integrated intensity measures were obtained using median background subtraction method. A standard curve was obtained using a linear fit with Prism 4.0 software (Graph$\mathrm{Pad}$ ) from integrated intensity values for known loads of caudal cortex. Sample values were interpolated from the standard curve as caudal cortex equivalents. Because the GIPC in the crude synaptosomes was not measurable in the standard loads, GAPDH was used to create a standard curve to calculate total GIPC coimmunoprecipitated with GluN2B. Each protein coimmunoprecipitated with GluN2B was expressed as a ratio of protein/GluN2B. Statistical analyses for both behavioral trials and protein expression were done with ANOVA followed by Fisher's protected least significant difference using Statview software (SAS Institute). Post hoc analyses of differences between each age group were planned based on previous studies of NMDA receptor aging. Pearson's correlation coefficients were calculated to assess the relationships between different protein precipitation ratios and reference memory (learning index).

\section{Results}

\section{Behavioral testing}

There was a significant effect of age on cumulative proximity in blocks of two place trials for spatial reference $\left(F_{(2,157)}=52.2, p<\right.$ $0.0001)$ and reversal $\left(F_{(2,157)}=11.3, p<0.0001\right.$; Fig. $\left.1 A, B\right)$ learning trials. The 26-month-old mice had significantly higher cumulative proximities in both spatial learning and reversal trials than both 3 - and 12-month-old mice ( $p \leq 0.0007$; Fig. $1 A, B$ ). High proximity scores indicate more time spent away from the platform. There was a significant effect of age on average proximity in probe trials $0-2\left(F_{(2,157)}=48.7, p<0.0001\right.$; Fig. $\left.1 C\right)$ and learning index scores $\left(F_{(2,157)}=47 ; p<0.0001\right.$; Fig. $\left.1 D\right)$ for spatial reference memory, with each older age group having significantly higher scores than each younger $(p<0.0001)$. The distribution of learning index scores for the groups of four animals that were combined for protein analysis is shown in Figure $1 E$. There was no significant effect of age on cumulative proximity in the cued trials $\left(F_{(2,157)}=2.2, p=0.12\right.$; Fig. $\left.1 F\right)$.

\section{Age-related changes in protein associations with GluN2B}

To determine whether GluN2B-containing NMDA receptors have a different membrane localization in aged mice, GluN2B antibodies were used to coimmunoprecipitate PSD-95, GIPC, and GluN2A from crude frontal cortex synaptosomal preparations of 3-, 12-, and 26-month-old mice (Fig. 2A). The behaviorally tested and naive animals did not differ significantly in the relative amount of each protein coimmunoprecipitated with GluN2B ( $p=0.46-0.97$; data not shown), therefore we concentrated only on animals that were behaviorally characterized for this report. The amount of GluN2B precipitated from frontal cortex lysates showed a near-significant overall effect of age $\left(F_{(2,34)}=2.847, p=0.07\right.$; Fig. $\left.2 B\right)$. There was significantly less GluN2B precipitated from the 26-month-old mice than the 3 -month-olds $(p=0.02$; Fig. $2 B)$. There was a significant main effect of age on the ratio of PSD-95/GluN2B $\left(F_{(2,31)}=8.994, p=\right.$
0.0007; Fig. 2C) and a near-significant main effect of age on the GluN2A/GluN2B ratio $\left(F_{(2,31)}=2.64, p=0.08\right.$; Fig. $\left.2 D\right)$, but not for $\operatorname{GIPC} / G l u N 2 B\left(F_{(2,34)}=0.832, p=0.44\right.$; Fig. $\left.2 E\right)$. There was a significantly higher ratio of PSD-95/GluN2B in the 26-monthold mice compared with both the 3 and 12-month-olds ( $p=$ 0.0003; Fig. 2C). Analysis of GluN2A/GluN2B ratios showed a significant increase with age between 3 - and 26-month-old mice $(p=0.03$; Fig. 2D).

\section{Relationships between protein associations and memory}

Pearson's correlation coefficients were calculated for the learning index scores in all three age groups and the ratios of proteins coimmunoprecipitated with GluN2B from combined brains. We were able to replicate past work by significantly correlating the amount of GluN2B precipitated with learning index scores across all ages ( $p<0.0001$; Fig. 3A; Magnusson et al., 2007). Lower amounts of GluN2B precipitated were associated with higher (poorer) learning index scores (Fig. 3A). Correlational analysis of PSD-95/GluN2B ratios to learning index scores revealed that a significantly greater number of PSD-95 proteins interact with GluN2B in animals with higher learning index scores across all ages $(p=0.001$; Fig. $3 B)$. Although there was no significant increase in the GIPC/GluN2B ratio with age, there was a significant correlation between the protein ratio and learning index scores across all ages ( $p=0.003$; Fig. $3 C)$. Higher GIPC/GluN2B ratios were associated with higher learning index scores. Because PSD-95 preferentially binds to GluN2A (Xu, 2011), we tested the hypothesis that increased association of PSD-95 with age might be due to an increase in triheteromeric (GluN1/GluN2A/ GluN2B) NMDA receptors. There was no significant correlation between learning index scores and GluN2A/GluN2B ratios ( $p=$ 0.48 ; Fig. 3D). This suggested that although the GluN2A/GluN2B ratios increased with age, the age-related memory deficits were related more to the relationship between PSD-95 and GluN2B, not between PSD-95 and GluN2A. To test this idea, we analyzed the correlation between GluN2A/GluN2B and PSD-95/GluN2B and found no significance $(p=0.56$; Fig. $3 E)$. We then looked at the correlation between GIPC/GluN2B and PSD-95/GluN2B. There 

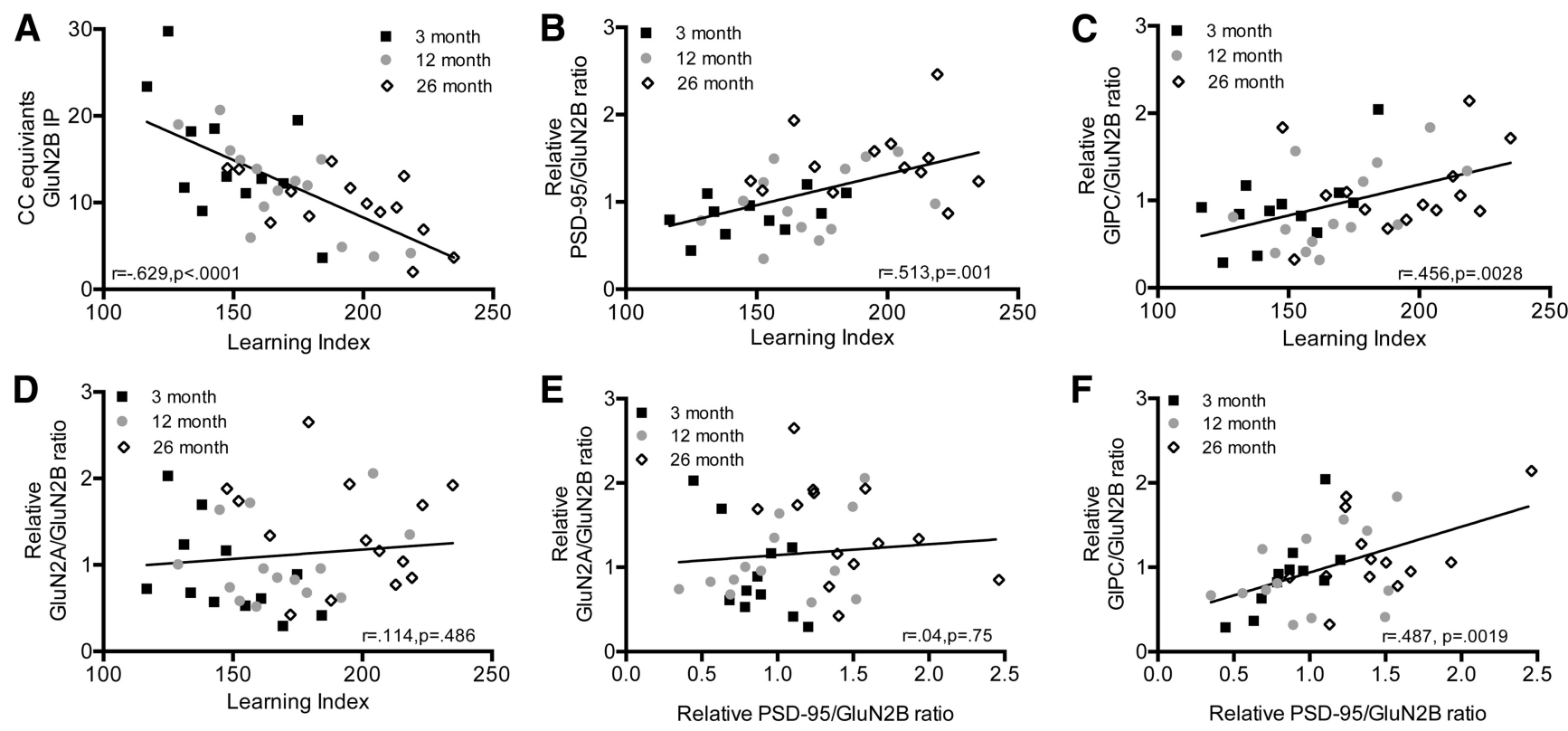

Figure 3. Correlation of GluN2B subunit complex proteins with spatial reference memory task. Significant correlations between learning indices and relative amounts of GluN2B immunoprecipitated $(\boldsymbol{A})$ or the ratios of PSD-95/GluN2B $(\boldsymbol{B})$ or GIPC/GluN2B (C) coimmunoprecipitated. GluN2A/GluN2B ratios did not correlate with learning index $(\boldsymbol{D})$ or PSD-95/GluN2B ratios $(\boldsymbol{E})$. $\boldsymbol{F}$, GIPC/GluN2B ratios correlated positively with PSD-95/GluN2B ratios; $N=11-14$. Data points are combinations of four brains within each of three age groups. $r$, Pearson correlation coefficient.

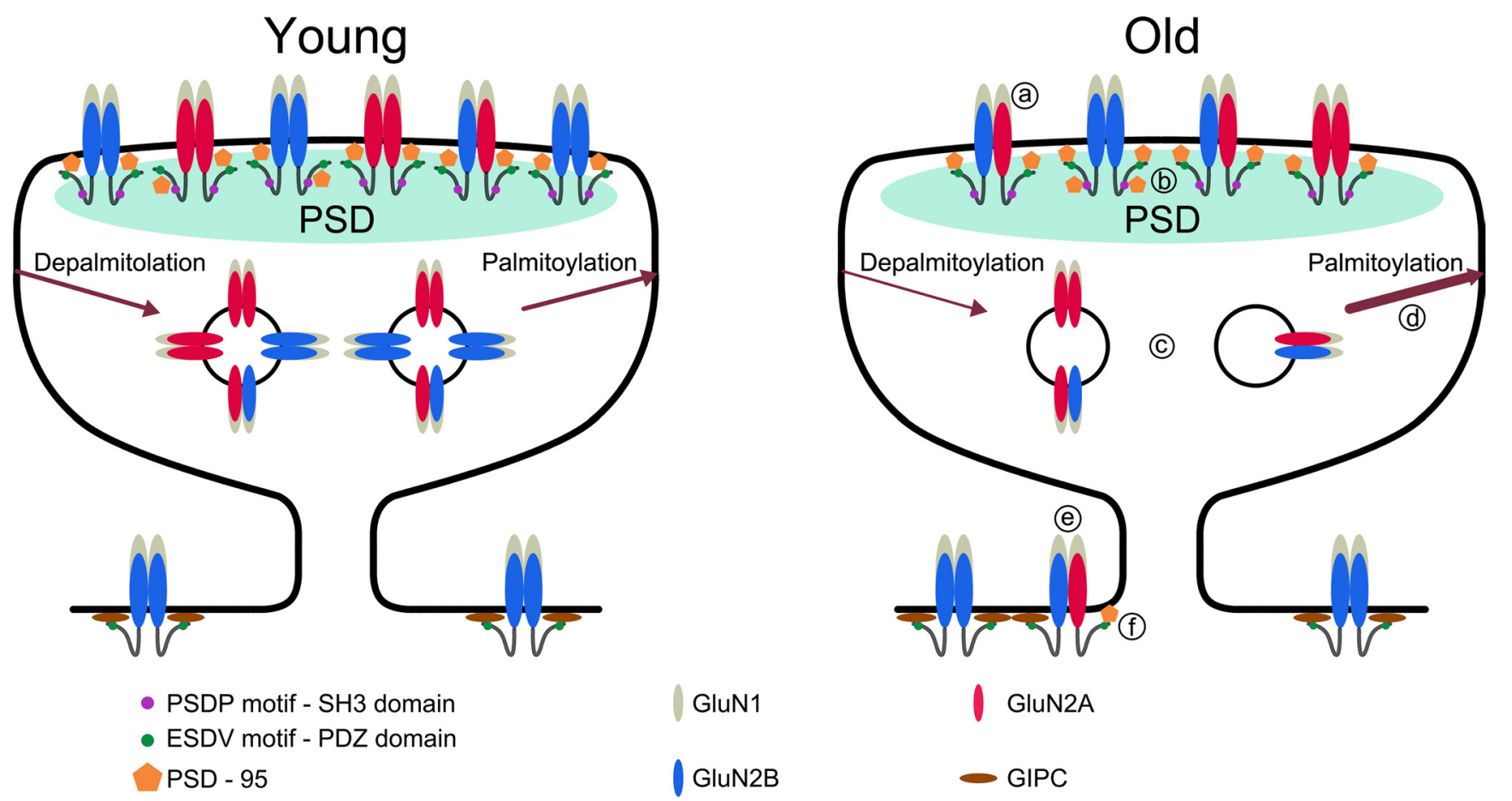

Figure 4. Potential mechanisms of age-related changes in glutamatergic synapses in the frontal cortex. Declines in synaptic membrane expression of GluN2B subunits (Zhao et al., 2009) and an increase in PSD-95/GluN2B ratio in aged frontal cortex associated with poor memory could be related to: $\boldsymbol{a}$, an increase in triheteromeric NMDA receptors; $\boldsymbol{b}$, an increase in the number of PSD-95 molecules per GluN2 subunit; and/or $\boldsymbol{c}$, decreased cycling of receptors off of the membrane, which may be influenced by increased palmitoylation of subunits and PSD-95 (d). Synaptic membrane decreases in GluN2B subunits and high GIPC/GluN2B ratios in frontal cortex being associated with high PSD-95/GluN2B ratios and poor memory could be caused by: $\boldsymbol{e}$, GluN2B-containing NMDA receptors being more mobile than those with GluN2A, which may allow triheteromeric receptors to traffic to extrasynaptic membranes where they interact with GIPC and/or $f$, PSD-95 being aberrantly located in the extrasynaptic membrane in the poorest old learners.

was a significant positive correlation between the two ratios in combined brains across all ages ( $p=0.0019$; Fig. $3 F)$.

\section{Discussion}

In this study we demonstrated that GluN2B and PSD-95 precipitated together to a greater degree in aged mice than in young mice. This increased interaction was significantly correlated with poorer performance in a spatial reference memory task, as assessed by the Morris water maze. We also found that an increased association of GIPC and GluN2B was related to a reduction in spatial reference memory across all ages. Finally, although the GluN2A/GluN2B ratio increased with age, suggesting that there 
was an increase in triheteromeric receptors with increased age, there was no relationship to spatial reference memory.

The GluN2A/GluN2B ratio increased significantly with age between the young and old mice, suggesting that there was an increase in triheteromeric receptors in the synaptic environment of aged mice. This is consistent with electrophysiological results from oocytes injected with mRNA from the frontal cortex of young or old mice; increased sensitivity to $\mathrm{Mg}^{2+}$ and a switch to more low affinity ifenprodil sites in old mice fits with a shift to increased GluN2A association with GluN2B (Kuehl-Kovarik et al., 2000). An increase in triheteromeric receptors could also account for the greater decline in GluN2B seen in the synaptic membrane than the tissue as a whole in previous work (Zhao et al., 2009). Recent evidence indicates that triheteromeric receptors predominate in the hippocampus of young adult mice (Rauner and Kohr, 2011). Our data suggested that, rather than just having a loss of GluN2B-containing NMDA receptors during aging in the frontal cortex, there was an increase in prevalence of triheteromeric receptors across adult aging (Fig. $4 a, e$ ). GluN2A is less mobile in synapses than GluN2B and is found mostly at the PSD, whereas GluN2B is often extrasynaptic (Barria and Malinow, 2002; Groc et al., 2006). The presence of both subunits may mean that triheteromeric receptors can be localized to extrasynaptic, as well as, synaptic membranes in aged animals (Fig. 4a,e), which could also contribute to age-related declines in GluN2B subunits in the synaptic membrane (Zhao et al., 2009).

There was no significant relationship between GluN2A/ GluN2B ratios and spatial reference memory. Nor was there a correlation between GluN2A/GluN2B and PSD-95/GluN2B ratios, suggesting that there was an additional increased PSD-95/ GluN2B interaction that was not accounted for by PSD-95 binding GluN2A. Although PSD-95 is predominantly localized near the synaptic membrane $(\mathrm{Xu}, 2011)$, this increased association of GluN2B with PSD-95 did not enhance spatial reference memory. A new report has found an additional binding site for PSD-95 on GluN2A and GluN2B C-terminal tails and implies that the ratio of PSD-95 to GluN2 subunit may not be 1:1, but, because PSD-95 can dimerize, could be as high as 4:1 (Cousins and Stephenson, 2012). In the hippocampus, a 40\% loss of synaptic GluN2B expression associated with aging is not matched by the $15 \%$ loss in PSD-95 expression, suggesting a greater effect of aging on the NMDA subunit (Magnusson et al., 2002; VanGuilder et al., 2010). The age-related decline in GluN2B expression in the synaptic membrane in frontal cortex may result in more molecules of PSD-95 binding to each GluN2B subunit than is seen in younger animals (Fig. 4b). PSD-95 is also able to cluster AMPA receptors via the scaffolding protein Stargazin, but there is evidence that stargazin preferentially binds PSD-93, whereas PSD-95 has a higher affinity for GluN2A (Stiffler et al., 2006; Elias and Nicoll, 2007). The increased association of PSD-95 to NMDA receptors may alter AMPA receptor clustering during aging; however, PSD-93 may act in a compensatory manner.

Data has shown that PSD-95 is able to concentrate NMDA receptors at the synapse (Roche et al., 2001). However, NMDA receptors are able to cluster on new synapses without PSD-95 (Washbourne et al., 2002), and blocking the ability of PSD-95 to cluster has no effect on NMDA receptor localization at synapses (Passafaro et al., 1999). Similarly, the synaptic localization of NMDA receptors was unaffected in PSD-95 mutant mice that displayed deficits in synaptic plasticity and spatial learning (Migaud et al., 1998). PSD-95 can enhance NMDA receptor clustering, but it seems that it is not necessary for proper localization of receptors, so it is not clear that the ability of PSD-95 to concen- trate NMDA receptors to the synapse is directly responsible for the memory declines during aging.

Higher GIPC/GluN2B ratios showed a relationship with poorer learning across all ages. GIPC is a scaffolding protein that binds via its PDZ region to GluN2-containing NMDA receptors preferentially on extrasynaptic membranes (Yi et al., 2007). Our results indicated that memory declines during aging may be related to an age-related increase in the proportion of the GluN2Bcontaining NMDA receptors that remain in old animals that were associated with surface membranes, both in and around synapses. Our data also showed that GIPC/GluN2B and PSD-95/ GluN2B ratios positively correlated across all ages, which may mean that there was a common mechanism influencing the alterations in association of GluN2B with these two scaffolding proteins. Recent evidence that PSD-95 can localize with NMDA receptors on extrasynaptic membranes (Fan et al., 2012) might explain this relationship (Fig. $4 f$ ).

Another potential mechanism could be a decrease in normal cycling of the receptors off of the membrane, resulting in a decrease in the population of internalized receptors for breakdown or recycling (Fig. 4c). An increased number of PSD-95 molecules per GluN2B, as mentioned above, or altered phosphorylation status (Goebel-Goody et al., 2009) might increase stabilization of receptors in the membrane. Preliminary work in our lab (unpublished observation) showed that a greater percentage of GluN2A, GluN2B, and PSD-95 proteins are palmitoylated in aged frontal cortex than in young. Palmitoylation stabilizes NMDA and AMPA receptors in the synaptic membrane and depalmitoylation is necessary to cycle the receptors off the membrane (Baekkeskov and Kanaani, 2009; Hayashi et al., 2009; Noritake et al., 2009). An increased number of palmitoylated proteins could explain an age-related increase in association of remaining GluN2B-containing NMDA receptors with the surface membrane (Fig. $4 d$ ).

In summary, there appeared to be an increase in triheteromeric receptors during aging, but this did not appear to influence spatial reference memory. Age-related memory declines were more related to an increased association of GluN2B-containing NMDA receptors with membrane scaffolding proteins.

\section{References}

Baekkeskov S, Kanaani J (2009) Palmitoylation cycles and regulation of protein function (Review). Mol Membr Biol 26:42-54. CrossRef Medline

Barnes CA (1979) Memory deficits associated with senescence: a neurophysiological and behavioral study in the rat. J Comp Physiol Psychol 93:74-104. CrossRef Medline

Barria A, Malinow R (2002) Subunit-specific NMDA receptor trafficking to synapses. Neuron 35:345-353. CrossRef Medline

Cousins SL, Stephenson FA (2012) Identification of N-methyl-D-aspartic acid (NMDA) receptor subtype-specific binding sites that mediate direct interactions with scaffold protein PSD-95. J Biol Chem 287:13465-13476. CrossRef Medline

Cui Y, Jin J, Zhang X, Xu H, Yang L, Du D, Zeng Q, Tsien JZ, Yu H, Cao X (2011) Forebrain NR2B overexpression facilitating the prefrontal cortex long-term potentiation and enhancing working memory function in mice. PLoS ONE 6:e20312. CrossRef Medline

Das SR, Jensen R, Kelsay R, Shumaker M, Bochart R, Brim B, Zamzow D, Magnusson KR (2012) Reducing expression of GluN1(0XX) subunit splice variants of the NMDA receptor interferes with spatial reference memory. Behav Brain Res 230:317-324. CrossRef Medline

Dunah AW, Standaert DG (2001) Dopamine D1 receptor-dependent trafficking of striatal NMDA glutamate receptors to the postsynaptic membrane. J Neurosci 21:5546-5558. Medline

Elias GM, Nicoll RA (2007) Synaptic trafficking of glutamate receptors by MAGUK scaffolding proteins. Trends Cell Biol 17:343-352. CrossRef Medline 
Fan J, Gladding CM, Wang L, Zhang LY, Kaufman AM, Milnerwood AJ, Raymond LA (2012) P38 MAPK is involved in enhanced NMDA receptor-dependent excitotoxicity in YAC transgenic mouse model of Huntington disease. Neurobiol Dis 45:999-1009. CrossRef Medline

Gallagher M, Burwell R, Burchinal M (1993) Severity of spatial learning impairment in aging: development of a learning index for performance in the Morris water maze. Behav Neurosci 107:618-626. CrossRef Medline

Goebel-Goody SM, Davies KD, Alvestad Linger RM, Freund RK, Browning MD (2009) Phospho-regulation of synaptic and extrasynaptic N-methyl-daspartate receptors in adult hippocampal slices. Neuroscience 158: 1446-1459. CrossRef Medline

Groc L, Heine M, Cousins SL, Stephenson FA, Lounis B, Cognet L, Choquet D (2006) NMDA receptor surface mobility depends on NR2A-2B subunits. Proc Natl Acad Sci U S A 103:18769-18774. CrossRef Medline

Hayashi T, Thomas GM, Huganir RL (2009) Dual palmitoylation of NR2 subunits regulates NMDA receptor trafficking. Neuron 64:213-226. CrossRef Medline

Kuehl-Kovarik MC, Magnusson KR, Premkumar LS, Partin KM (2000) Electrophysiological analysis of NMDA receptor subunit changes in the aging mouse cortex. Mech Ageing Dev 115:39-59. CrossRef Medline

Low CM, Wee KS (2010) New insights into the not-so-new NR3 subunits of $\mathrm{N}$-methyl-D-aspartate receptor: localization, structure, and function. Mol Pharmacol 78:1-11. CrossRef Medline

Magnusson KR (2000) Declines in mRNA expression of different subunits may account for differential effects of aging on agonist and antagonist binding to the NMDA receptor. J Neurosci 20:1666-1674. Medline

Magnusson KR, Nelson SE, Young AB (2002) Age-related changes in the protein expression of subunits of the NMDA receptor. Brain Res Mol Brain Res 99:40-45. CrossRef Medline

Magnusson KR, Scruggs B, Zhao X, Hammersmark R (2007) Age-related declines in a two-day reference memory task are associated with changes in NMDA receptor subunits in mice. BMC Neurosci 8:43. CrossRef Medline

Migaud M, Charlesworth P, Dempster M, Webster LC, Watabe AM, Makhinson M, He Y, Ramsay MF, Morris RG, Morrison JH, O’Dell TJ, Grant SG (1998) Enhanced long-term potentiation and impaired learning in mice with mutant postsynaptic density-95 protein. Nature 396:433-439. CrossRef Medline

Morris RG, Anderson E, Lynch GS, Baudry M (1986) Selective impairment of learning and blockade of long-term potentiation by an N-methyl-Daspartate receptor antagonist, AP5. Nature 319:774-776. CrossRef Medline

Muller WE, Stoll S, Scheuer K, Meichelbock A (1994) The function of the NMDA-receptor during normal brain aging. J Neural Transm Suppl 44: 145-158. Medline

Noritake J, Fukata Y, Iwanaga T, Hosomi N, Tsutsumi R, Matsuda N, Tani H,
Iwanari H, Mochizuki Y, Kodama T, Matsuura Y, Bredt DS, Hamakubo T, Fukata M (2009) Mobile DHHC palmitoylating enzyme mediates activity-sensitive synaptic targeting of PSD-95. J Cell Biol 186:147-160. CrossRef Medline

Passafaro M, Sala C, Niethammer M, Sheng M (1999) Microtubule binding by CRIPT and its potential role in the synaptic clustering of PSD-95. Nat Neurosci 2:1063-1069. CrossRef Medline

Rauner C, Köhr G (2011) Triheteromeric NR1/NR2A/NR2B receptors constitute the major $\mathrm{N}$-methyl-D-aspartate receptor population in adult hippocampal synapses. J Biol Chem 286:7558-7566. CrossRef Medline

Roche KW, Standley S, McCallum J, Dune Ly C, Ehlers MD, Wenthold RJ (2001) Molecular determinants of NMDA receptor internalization. Nat Neurosci 4:794-802. CrossRef Medline

Scheuer K, Stoll S, Paschke U, Weigel R, Müller WE (1995) N-methyl-Daspartate receptor density and membrane fluidity as possible determinants of the decline of passive avoidance performance in aging. Pharmacol Biochem Behav 50:65-70. CrossRef Medline

Stiffler MA, Grantcharova VP, Sevecka M, MacBeath G (2006) Uncovering quantitative protein interaction networks for mouse PDZ domains using protein microarrays. J Am Chem Soc 128:5913-5922. CrossRef Medline

Tang YP, Shimizu E, Dube GR, Rampon C, Kerchner GA, Zhuo M, Liu G, Tsien JZ (1999) Genetic enhancement of learning and memory in mice. Nature 401:63-69. CrossRef Medline

VanGuilder HD, Yan H, Farley JA, Sonntag WE, Freeman WM (2010) Aging alters the expression of neurotransmission-regulating proteins in the hippocampal synaptoproteome. J Neurochem 113:1577-1588. CrossRef Medline

Washbourne P, Bennett JE, McAllister AK (2002) Rapid recruitment of NMDA receptor transport packets to nascent synapses. Nat Neurosci 5:751-759. CrossRef Medline

Xu W (2011) PSD-95-like membrane associated guanylate kinases (PSDMAGUKs) and synaptic plasticity. Curr Opin Neurobiol 21:306-312. CrossRef Medline

Yi Z, Petralia RS, Fu Z, Swanwick CC, Wang YX, Prybylowski K, Sans N, Vicini S, Wenthold RJ (2007) The role of the PDZ protein GIPC in regulating NMDA receptor trafficking. J Neurosci 27:11663-11675. CrossRef Medline

Zhao MG, Toyoda H, Lee YS, Wu LJ, Ko SW, Zhang XH, Jia Y, Shum F, Xu H, Li BM, Kaang BK, Zhuo M (2005) Roles of NMDA NR2B subtype receptor in prefrontal long-term potentiation and contextual fear memory. Neuron 47:859-872. CrossRef Medline

Zhao X, Rosenke R, Kronemann D, Brim B, Das SR, Dunah AW, Magnusson KR (2009) The effects of aging on $N$-methyl-d-aspartate receptor subunits in the synaptic membrane and relationships to long-term spatial memory. Neuroscience 162:933-945. CrossRef Medline 